\title{
The COVID-19 pandemic and airline cash flow
}

\author{
B. Vinod ${ }^{1}$
}

Received: 15 April 2020 / Accepted: 22 May 2020 / Published online: 20 June 2020

(c) Springer Nature Limited 2020

\begin{abstract}
The novel coronavirus pandemic has had a seismic impact on the travel industry. With a steep drop in demand and flight cancelations on international routes, airlines have reduced capacity on a scale that we have never seen before. In the current environment, airlines are strapped for cash, and cashflow is a prerequisite for survival. As airlines navigate through the resumption of flights in a Covid-19 and post-Covid-19 era, this paper recommends an approach for airlines to generate cashflow from corporations for their mutual benefit.
\end{abstract}

Keywords Coronavirus pandemic · COVID-19 - Airline cash flow · Corporate fares

The coronavirus outbreak that started in December 2019 in Wuhan, China has had a seismic impact on the travel industry. With the virus in our midst, we live in unprecedented times. To contain the spread of the virus, non-essential businesses large and small have been mandated to shut down (e.g., restaurants) and corporate employers have new work-from-home policies. The travel sector has also been impacted severely. Cruise lines and hotels were impacted on a larger scale than airlines who could at least fly cargo if not passengers due to the absence of passenger demand for flights. International airlines stopped operating flights into and out of China in February 2020. This was followed with capacity reductions across the Asia-Pacific region. After the COVID-19 outbreak worldwide starting in February, airlines have been forced to cut capacity on a scale that we have never seen before. Capacity reductions even dwarf the fallout from the terrorist attacks from September 11, 2001 and IATA predicts that cumulative airline losses could exceed 250 billion dollars (RT 2020). For example, United Airlines has cut capacity by $80 \%$ (Witkowski 2020). It is unlikely that travel will rebound to 2019 levels until an effective vaccine can be produced at scale. Even after a vaccine, recovery could take $2-3$ years. While countries worldwide deal with containing the spread of the virus with social distancing and shelter-in-place orders from state, city, and local authorities, the virus is still in our midst.

Like other businesses, US domestic travel is expected to slowly rebound in the second half of 2020 as the number of coronavirus new cases and deaths recede from the peaks in March-May 2020. International is expected to rebound in 2021.

The airline industry is asset intensive and heavily leveraged. In the current environment, airlines are strapped for cash, and cashflow is a prerequisite for survival. So, the fundamental question is whether a marketplace for airline seat inventory exists that provided value to buyers and sellers. Seat inventory can be monetized so that corporations can prepay for travel and receive a discount. To make this model work, it should provide value to both the buyers (corporations) and sellers (airlines).

The marketplace economics for the buy-side is to aggregate travel requests by market across corporations by airline to facilitate group buy at a greater corporate discount than can be achieved by a corporation individually. The marketplace economics for the sell-side is for airlines to provide access to markets at a deeper discount for pre-purchase. Buyer activity and demand will influence future schedules in a post-COVID-19 world.

B. Vinod

benvinod@yahoo.com

1 Sabre Research, 3150 Sabre Drive, Southlake, TX 76092 , USA 


\section{What needs to change with corporate fares}

In the current environment, corporations negotiate a percentage discount off the selling ADT (adult, public fares) with airlines. Hence the discount floats with the available ADT fares. This is implemented as a fare by rule (ATPCo (Airline Tariff Publishing Company) Category 25) where the discount is applied. The buying and selling of corporate fares are controlled by the following APTCo rule categories:

- Category 1 defines who can buy (the corporation, at the negotiated discount)

- Category 15/35 defines who can sell (the travel management company (TMC) that manages the corporate travel spend for a corporation).

- The Category 25 corporate discount only applies to the top $\mathrm{N}$ booking classes based on the value of the fare. Hence when a flight is wide open, a leisure ADT fare for which the Category 25 discount does not apply could be cheaper than the lowest booking class (also open) for which the Category 25 corporate discount applies

Volume commitments are implicit and are rarely specified in contracts today. The Category 25 discount for a corporation is reflective of an airline's view of the corporation's commitment to ticketed sales in a year.

This model can be tweaked to generate cashflow for airlines. Airlines should be willing to give a steeper discount that is applicable across all or most booking classes based on ticketed sales volumes committed by a corporation to airlines. This can be specified by market, valid routing, seasonality, and departure month. The negotiated volume represents the maximum seat inventory that can be purchased as part of a "bulk buy" that provides a cash infusion with prepay to airlines. Incremental sales beyond the minimum will be ticketed at the standard corporate discount levels. This will require real-time tracking of booking activity to know when corporate discounts should revert from the ultradeep discount to the standard discounts for corporate fares. Since corporate travel is typically booked within 30 days of travel, the prepayment to airlines should be made on a monthly or quarterly basis.

Such an approach and its variations should provide an infusion of cash to cash-strapped airlines to continue daily operations. In return for a lump sum prepayment, corporations benefit with deeper discounts on corporate fares. This model should work during the interim period until a vaccine is found and travel rebounds to 2019 levels which according to most estimates is at least 2-3 years away.

\section{References}

RT. 2020. 'Deepest crisis ever': Covid-19's effect on airlines dwarfs 9/11 fallout, says industry. https://www.rt.com/news/48482 9-coronavirus-airline-industry-crisis/. Accessed $2 \mathrm{Apr}$

Witkowski, W. 2020. United Airlines cuts $80 \%$ of capacity, expects bigger reduction in May. https://www.marketwatch.com/story /united-airlines-cuts-80-of-capacity-expects-bigger-reduc tion-in-may-2020-04-03

Publisher's Note Springer Nature remains neutral with regard to jurisdictional claims in published maps and institutional affiliations.

B. Vinod serves as Senior Vice President and Chief Scientist at Sabre. Before rejoining Sabre in 2004, he was Vice President of Sabre Airline Solutions, responsible for pricing and yield management. 